\title{
Influence of Cooling Rate on Microstructure and Mechanical Properties of 42SiCr Steel after Q\&P Process
}

Tomáš Janda, Hana Jirková, Štěpán Jeníček, Ludmila Kučerová

Regional Technological Institute, University of West Bohemia, Univerzitní 22, 30614 Plzeň, Czech Republic. E-mail: jandat@rti.zcu.cz, hstankov@rti.zcu.cz, jeniceks@ rti.zcu.cz, skal@rti.zcu.cz.

Using innovative methods of heat treatment (HT) for high-strength steels, such as the Q\&P process, very favourable ratios of ductility and strength can be achieved. Materials processed by this technology have higher content of retained austenite, and therefore better ductility. This experiment deals with HT of $42 \mathrm{SiCr}$ steel. The conventional HT and the Q\&P processing are compared with respect to material properties. Metallographic analysis, hardness measurement, $X$-ray diffraction phase analysis (of retained austenite content) and tensile testing were performed. For the hardened samples, the effects of the cooling rate on their microstructure were assessed and the measured real-world data were compared with the simulations performed in the FEA simulation software DEFORM $^{\mathrm{TM}}$ based on the thermocouple records. After a conventional HT, the material showed little sensitivity to the cooling rate. In contrast, the $Q \& P$ process with higher quenching temperatures resulted in a higher austenite content and elongation of up to $15 \%$ at a strength of $1800 \mathrm{MPa}$.

Keywords: High-strength steel, heat treatment, Q\&P process, FE simulation

\section{Introduction}

Nowadays advanced high-strength materials have to meet ever stricter requirements for safety and economy of constructions. Therefore high strength as well as appropriate ductility are desired. In high-strength steels, an appropriate ratio of strength and elongation can be attained using the Q\&P process (Quenching and Partitioning). This process means that steel is quenched at a certain temperature (below the $\mathrm{M}_{\mathrm{s}}$ ) and then hold at the partitioning temperature. The quenching provides a martensitic microstructure with a certain retained austenite content. The following dwell at the partitioning temperature enables migration of carbon from supersaturated martensite into retained austenite (RA), making RA stable. The desired final microstructure should consist of martensite and a small volume fraction (5-10\%) of retained austenite which has a thin film morphology and is stable at room temperature [1-3]. Appropriately-treated steels with convenient composition can reach ultimate tensile strengths (UTS) in excess of $2000 \mathrm{MPa}$ and elongation higher than $10 \%[3,4]$.

One of the suitable materials for the Q\&P process treatment is a $42 \mathrm{SiCr}$ steel [5]. Some results of the experiments with this steel carried out in our institute have been published recently. In 2012 Jirková et al. [6] investigated the effects of manganese and silicon on the steel properties after Q\&P processing using a thermomechanical simulator (the technology using resistance heating of small specimens and water spray quenching). The effect of quenching and partitioning temperatures was also tested. Another experiment [7] focused on the influence of quenching and partitioning temperatures on the mechanical properties of the steel was carried out using a laboratory furnace and intermittent quenching in water and salt baths.

It was verified that the fraction of untransformed austenite grows with increasing quenching temperature (above $\mathrm{M}_{\mathrm{f}}$ ), resulting in an increase in elongation and simultaneously decrease in UTS. Therefore an optimal quenching and partitioning temperature must be found and applied. Both experiments indicate the optimal quenching temperature of $200{ }^{\circ} \mathrm{C}$ and subsequently the partitioning temperature of $250^{\circ} \mathrm{C}$, which result in UTS of $1995 \mathrm{MPa}$ and elongation of $15 \%[6,7]$.

This paper deals with the influence of cooling rate (from austenitizing temperature) on microstructure and mechanical properties of $42 \mathrm{SiCr}$ steel. The rate of cooling depends on the quenching media used (as well as its temperature) and affects the nature of the phase transformations in the material. It can affect uniformity of the microstructure and the volume fraction of RA in martensitic microstructure that is fundamental for later partitioning of carbon and RA stabilization. Various quenching agents were selected not only to improve the mechanical properties but also with respect to the ecology of the process. Different partitioning temperatures and dwells were tested in order to obtain complete results.

\section{Experiments}

High-strength $42 \mathrm{SiCr}$ steel was chosen as the experimental material (Tab. 1). Increased silicon content helps stabilize austenite, and therefore contributes to larger amounts of retained austenite in the final microstructure after austenite decomposition [5]. The initial stock consisted of rolled strips $10 \mathrm{~mm}$ in thickness. Samples of approximately $110 \times 85 \times 10 \mathrm{~mm}$ were cut using waterjet from the strips. The as-received microstructure was mixture of a majority of martensite and bainite with small amounts of pearlite and free ferrite. Prior to experimental heat treatment $(\mathrm{HT})$, the samples were homogenized $(\mathrm{H})$ at $1100^{\circ} \mathrm{C}$ for 4 hours in a furnace with an argon atmosphere. The resulting pearlitic microstructure contained a small amount of ferrite in the form of grains on prior austenite grain boundaries. Its hardness was 281 HV10. 
Tab. 1 Chemical composition of and temperatures of martensitic transformation in 42SiC.

\begin{tabular}{|c|c|c|c|c|c|c|c|c|c|c|c|}
\hline $\mathrm{C}$ & $\mathrm{Si}$ & $\mathrm{Mn}$ & $\mathrm{P}$ & $\mathrm{S}$ & $\mathrm{Cr}$ & $\mathrm{Mo}$ & $\mathrm{Ni}$ & $\mathrm{Al}$ & $\mathrm{Nb}$ & $\begin{array}{c}\mathrm{Ms} \\
{\left[{ }^{\circ} \mathrm{C}\right]}\end{array}$ & $\begin{array}{c}\mathrm{Mf} \\
{\left[{ }^{\circ} \mathrm{C}\right]}\end{array}$ \\
\hline 0.43 & 2.03 & 0.59 & 0.009 & 0.004 & 1.33 & 0.03 & 0.07 & 0.008 & 0.03 & 298 & 178 \\
\hline
\end{tabular}

Some specimens taken from the annealed plates were conventionally heat-treated using various quenchants. Others were unconventionally treated using Q\&P processing with various parameters (Tabs. 2 and 3 ). They were placed for 20 minutes into laboratory furnaces at $950^{\circ} \mathrm{C}$ with no protective atmosphere, and then quenched. The treatment was recorded by means of a thermocouple placed inside a hole drilled in one of the specimen sides. Using these readings, cooling curves and models for heat treatment simulations were constructed. Metallographic examination of the specimens was performed using optical and scanning electron microscopy. Their hardness was measured. X-ray diffraction phase analysis was employed to determine the fraction of retained austenite and to compare the effects of cooling rates in selected treatment sequences which ended with either quenching or tempering. Static tensile testing was carried on the treated materials.

In untempered specimens quenched in various quenchants and in a specimen which had cooled in air, the impact of the cooling rate on microstructure was studied. In addition, the data from FE simulations were compared against readings from the real-world specimens. Comparisons and contrasts were sought between the microstructures and mechanical properties of all quenched and tempered specimens and the Q\&P-processed ones. Using the Q\&P process the findings from the first stage of the experiment were tested and verified. The goal was to identify the heat treatment sequence which delivers the best ratio of tensile strength and elongation with respect to selection of a quenchant.

Tab. 2 Conventional treatment sequences

\begin{tabular}{|c|c|c|c|c|c|c|c|c|c|c|c|c|c|c|}
\hline \multirow{3}{*}{ Series } & \multirow{3}{*}{ Quenchant } & \multicolumn{13}{|c|}{ Sequence numbers for tempering parameters } \\
\hline & & \multirow{2}{*}{$\begin{array}{c}\text { Quen- } \\
\text { ching } \\
\text { only }\end{array}$} & \multicolumn{3}{|c|}{ Temperature $200^{\circ} \mathrm{C}$} & \multicolumn{3}{|c|}{ Temperature $250^{\circ} \mathrm{C}$} & \multicolumn{3}{|c|}{ Temperature $300^{\circ} \mathrm{C}$} & \multicolumn{3}{|c|}{ Temperature $350^{\circ} \mathrm{C}$} \\
\hline & & & $\begin{array}{c}30 \\
\text { min }\end{array}$ & $\begin{array}{c}60 \\
\min \end{array}$ & $\begin{array}{l}120 \\
\text { min }\end{array}$ & $\begin{array}{c}30 \\
\text { min }\end{array}$ & $\begin{array}{c}60 \\
\text { min }\end{array}$ & $\begin{array}{l}120 \\
\text { min }\end{array}$ & $\begin{array}{c}30 \\
\text { min }\end{array}$ & $\begin{array}{c}60 \\
\text { min }\end{array}$ & $\begin{array}{l}120 \\
\text { min }\end{array}$ & $\begin{array}{c}30 \\
\text { min }\end{array}$ & $\begin{array}{c}60 \\
\min \end{array}$ & $\begin{array}{l}120 \\
\text { min }\end{array}$ \\
\hline $\mathrm{H} 0-\mathrm{AC}$ & Air & 0 & - & - & - & - & - & - & - & - & - & - & - & - \\
\hline KP01 & Water $25^{\circ} \mathrm{C}$ & 0 & 1 & 2 & 3 & 4 & 5 & 6 & 7 & 8 & 9 & 10 & 11 & 12 \\
\hline KP02 & Oil $80^{\circ} \mathrm{C}$ & 0 & 1 & 2 & 3 & 4 & 5 & 6 & 7 & 8 & 9 & 10 & 11 & 12 \\
\hline KP03 & Salt $150^{\circ} \mathrm{C}$ & 0 & 1 & 2 & 3 & 4 & 5 & 6 & 7 & 8 & 9 & 10 & 11 & 12 \\
\hline
\end{tabular}

Tab. 3 Q\&P process sequences

\begin{tabular}{|c|c|c|c|c|c|c|c|c|c|c|c|c|c|}
\hline \multirow{3}{*}{ Series } & \multirow{3}{*}{ Quenchant } & \multicolumn{12}{|c|}{ Sequence numbers for partitioning parameters } \\
\hline & & \multicolumn{3}{|c|}{ Temperature $200^{\circ} \mathrm{C}$} & \multicolumn{3}{|c|}{ Temperature $250^{\circ} \mathrm{C}$} & \multicolumn{3}{|c|}{ Temperature $300^{\circ} \mathrm{C}$} & \multicolumn{3}{|c|}{ Temperature $350^{\circ} \mathrm{C}$} \\
\hline & & $\begin{array}{c}0 \\
\min \end{array}$ & $\begin{array}{c}10 \\
\min \end{array}$ & $\begin{array}{c}30 \\
\min \end{array}$ & $\begin{array}{c}0 \\
\min \end{array}$ & $\begin{array}{c}10 \\
\min \end{array}$ & $\begin{array}{r}30 \\
\text { min }\end{array}$ & $\begin{array}{c}0 \\
\min \end{array}$ & $\begin{array}{c}10 \\
\min \end{array}$ & $\begin{array}{r}30 \\
\mathrm{~min}\end{array}$ & $\begin{array}{c}0 \\
\min \end{array}$ & $\begin{array}{c}10 \\
\min \end{array}$ & $\begin{array}{r}30 \\
\text { min }\end{array}$ \\
\hline QP05 & Salt $200^{\circ} \mathrm{C}$ & 1 & 2 & 3 & 4 & 5 & 6 & 7 & 8 & 9 & 10 & 11 & 12 \\
\hline QP06 & Salt $250^{\circ} \mathrm{C}$ & - & - & - & 4 & 5 & 6 & 7 & 8 & 9 & 10 & 11 & 12 \\
\hline
\end{tabular}

Based on values from the thermocouple and material data calculated with the JMatPro software (validated by dilatometer measurement), numerical modelling of water quenching (sequence KP01-00) was performed with DEFORM $^{\mathrm{TM}}$ [8]. As the specimen was symmetrical, only $1 / 4$ of it was included in the model. Denser mesh was created around the thermocouple location (top left corner of the model, which in fact was the mid-point of one side of the entire specimen). Microstructural evolution was simulated and cooling curves generated for several locations across the specimen to provide comparison with metallographic analysis of the real-world specimen.

Hardness profiles (HV1) across the specimen thickness were measured on the selected quenched specimens, on the specimen cooled in still air and on the prehomogenized specimen. Three profiles were obtained for each specimen: at $0.3 \mathrm{~mm}, 5 \mathrm{~mm}$ and $10 \mathrm{~mm}$ from the specimen side. The indentations nearest to the surface were made at $0.2 \mathrm{~mm}$ depth, after considering surface decarburization. The other indentations were spaced at $0.5 \mathrm{~mm}$. Hardness HV10 was measured on specimens obtained from all HT sequences.

Tensile test specimens were round bars $5.0 \mathrm{~mm}$ in diameter, with a gauge length of $25 \mathrm{~mm}$, which yielded A5.65 elongation values.

\section{Results and discussion}

First, a specimen fitted with a thermocouple was quenched from $950^{\circ} \mathrm{C}$ with various quenchants. The cooling curves (Fig. 1a) constructed from the thermocouple data clearly show the differences between the cooling processes in various quenchants. Cooling (to the $\mathrm{M}_{\mathrm{s}}$ ) was the fastest in water at $90^{\circ} \mathrm{C} / \mathrm{s}$. Water cooling was expected to produce the highest hardness and steepest hardness gradient across the specimen thickness. Cooling rates in oil and 
salt bath were comparable, about $25-30^{\circ} \mathrm{C} / \mathrm{s}$. The curves only began to split near the quenchant temperature $(80$ and $150^{\circ} \mathrm{C}$ ). At slower cooling rates, a gentler gradient across the specimen thickness and a higher volume fraction of retained austenite can be expected. The cooling rate in still air was about $1{ }^{\circ} \mathrm{C} / \mathrm{s}$. Several series of specimens were quenched in the salt bath at various temperatures $\left(150,200\right.$ and $\left.250^{\circ} \mathrm{C}\right)$.
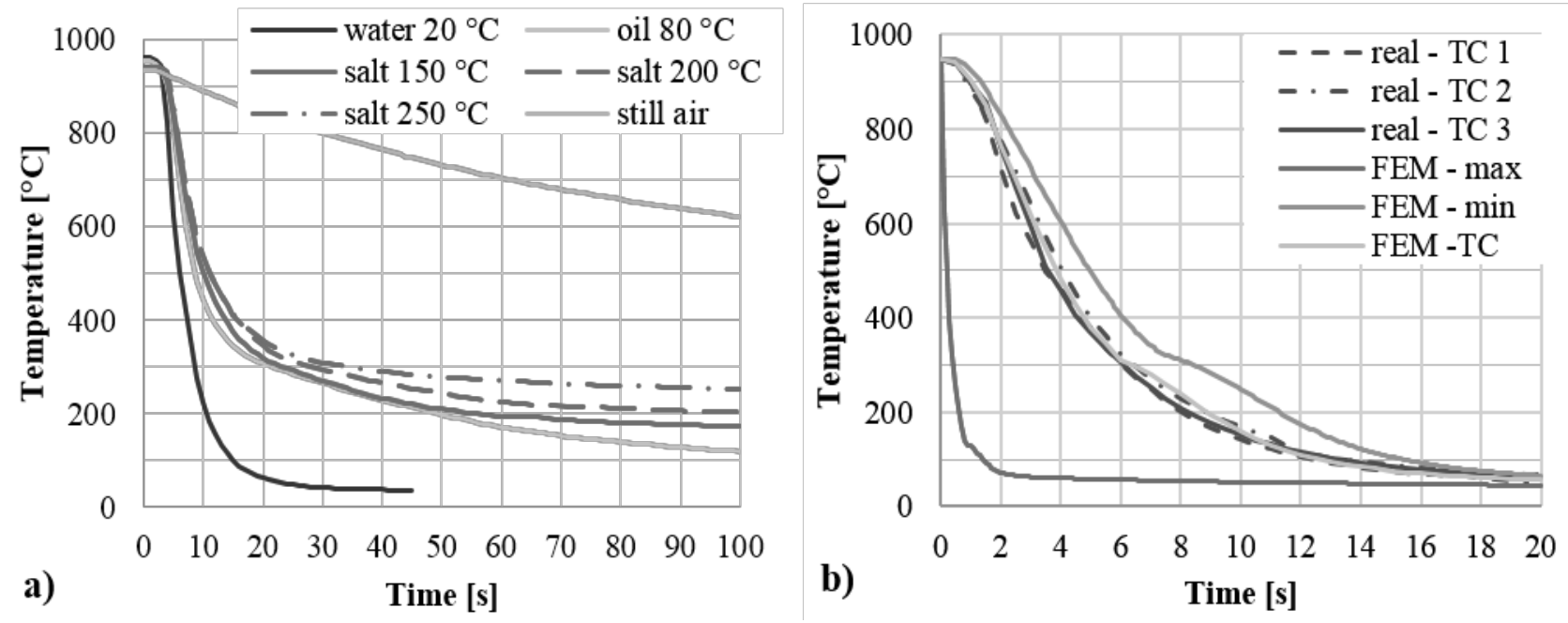

Fig. 1 a) Cooling rates of specimens in various quenchants, b) Cooling rates in various locations of a specimen calculated using FEA for sequence KP01-00 and comparison with thermocouple data.
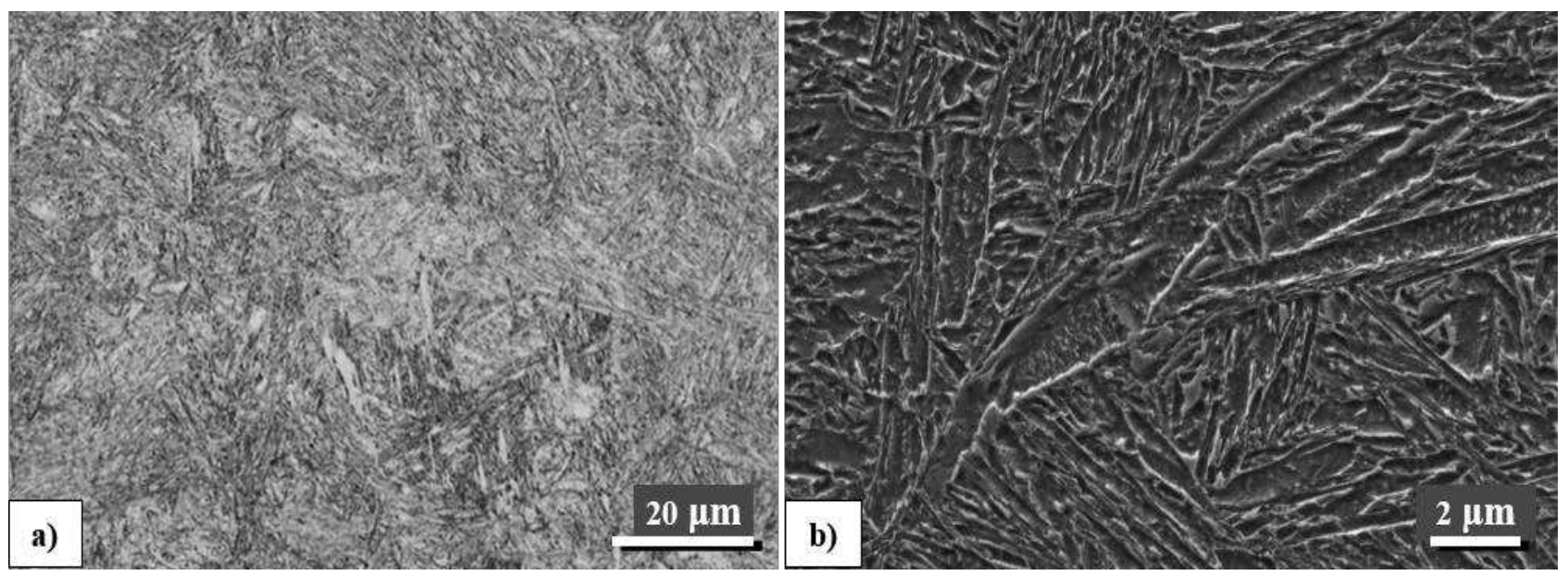

Fig. 2 Micrographs of specimen KP03-09 (quenched in salt bath, tempered at $300^{\circ} \mathrm{C}$, time: 120 minutes): a) optical micrograph, b) scanning electron micrograph.

Metallographic analysis revealed martensitic microstructures with small amounts of bainite in all specimens: as-quenched, quenched and tempered and Q\&Pprocessed (Fig. 2). Free proeutectoid ferrite was not detected even upon the sequence with a slow rate of cooling in still air. No tempered or Q\&P-processed specimen showed signs of extensive precipitation of carbides. These findings suggest that the alloying strategy was correct, as the alloy additions included chromium (a carbide former), manganese and silicon, which suppresses precipitation. In specimens quenched in the salt bath, a higher amount of retained austenite was found by X-ray diffraction (Tab. 4). The volume fraction of retained austenite increased with temperature and tempering time (Tab. 4), which should be reflected in mechanical properties (namely higher elongation).

Tab. 4 Amounts of retained austenite in specimens cooled in various quenchants and tempered to various parameters.

\begin{tabular}{|c|c|c|c|c|c|}
\hline \multirow{2}{*}{ Quenchant } & \multicolumn{5}{|c|}{ Volume fractions [\%] of retained austenite upon various tempering sequences } \\
\cline { 2 - 6 } & Untempered & $\mathbf{2 0 0}^{\circ} \mathbf{C} / \mathbf{3 0} \mathbf{m i n}$ & $\mathbf{2 0 0}^{\circ} \mathbf{C} / \mathbf{1 2 0} \mathbf{~ m i n}$ & $\mathbf{2 5 0}^{\circ} \mathbf{C} / \mathbf{6 0}^{\mathbf{m i n}}$ & $\mathbf{3 5 0} \mathbf{C}^{\circ} \mathbf{C} \mathbf{1 2 0} \mathbf{~ m i n}$ \\
\hline Water $\mathbf{2 0}{ }^{\circ} \mathbf{C}$ & 4 & 4 & 4 & 5 & 7 \\
\hline Salt $150^{\circ} \mathbf{C}$ & 6 & 8 & 8 & 8 & 7 \\
\hline
\end{tabular}

FE models predicted that the specimens would have martensitic microstructures with a small amount of retained austenite and negligible fractions of bainite and pearlite. Fig. 3 illustrates the predicted amounts of martensite and retained austenite in a water-quenched specimen. It shows that hardening would be uniform across the specimen cross section (martensite fractions: 98.5-99.1\%). The simulations also yielded the cooling curves in fastest- 
cooling and slowest-cooling locations and at the point of attachment of the thermocouple. Cooling curves measured with thermocouples (Real-TC1 to TC3) were added to relevant graphs for comparison. Results of FE modelling and metallographic observation confirmed that the specimens, including the water-quenched one, have hardened uniformly throughout their section and developed no hardness gradient. For this reason, no further FE simulations of material behaviour and cooling rates for various locations in the specimens were carried out. a)

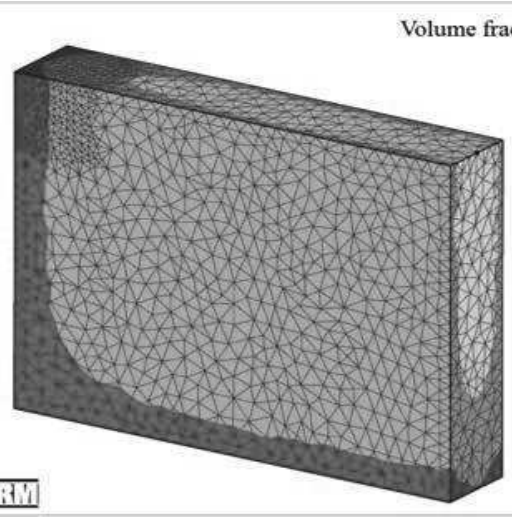

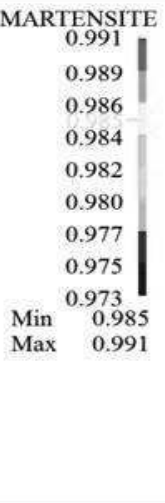

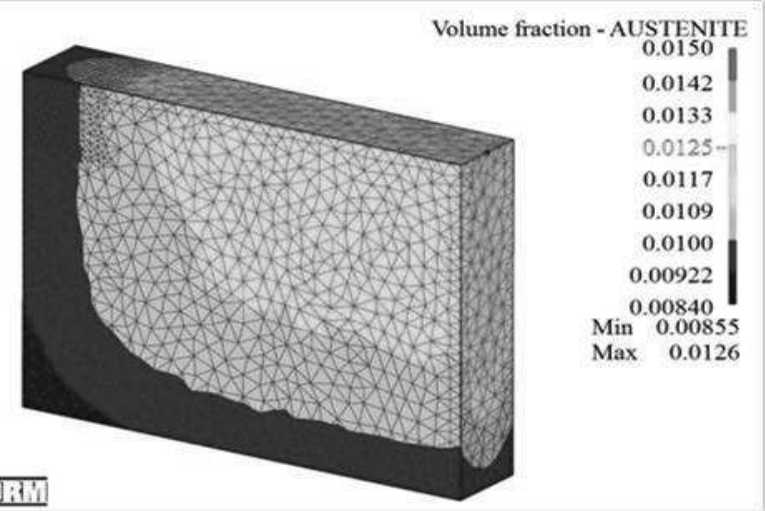

Fig. 3 Simulated phase composition of a specimen: a) martensite volume fraction, b) retained austenite volume fraction. In the top left corner of the model, i.e. the thermocouple location, increased mesh density is used.

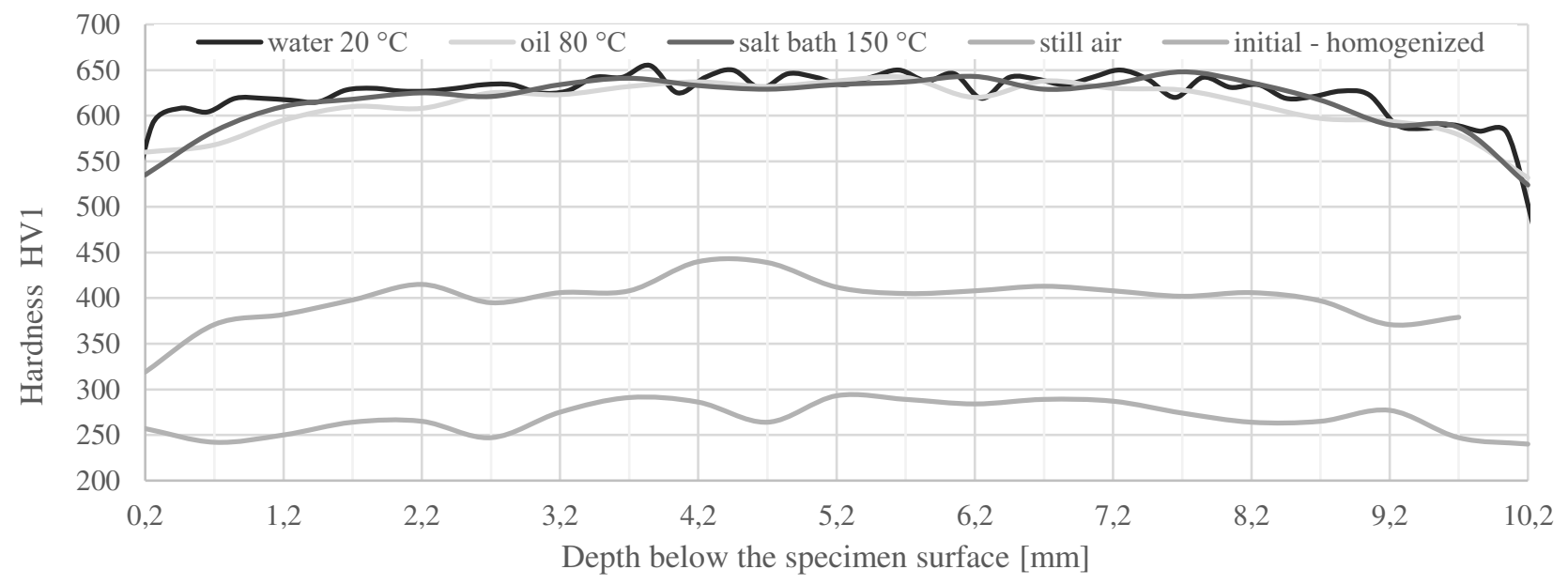

Fig. 4 Hardness profiles on a cross-section through a specimen $5 \mathrm{~mm}$ from its edge

Measurement of hardness profiles across specimen thickness was proposed for untempered specimens. The first profiles were acquired from the water-quenched specimen. Three different profiles were measured: on the side of the specimen (at $0.3 \mathrm{~mm}$ depth) and at $5 \mathrm{~mm}$ and $10 \mathrm{~mm}$ below the side surface. These measurements have not revealed any variation among hardness profiles in different locations of the specimen. Therefore, the measurements on all other specimens were only taken at $5 \mathrm{~mm}$ distance from the specimen edge. Hardness was rising between the surface and a depth of about $2.0 \mathrm{~mm}$, where it levelled off at $640 \mathrm{HV} 1$. The same occurrence was found on the opposite surface. It was also confirmed in the pre-homogenized specimen, although its hardness levels was different: about 280 HV1 (Fig. 4). This indicates that the chemical composition of the initial material was non-uniform, possibly due to decarburization during strip rolling. The decarburization hypothesis was supported by metallographic observation which confirmed decarburization down to $1.0 \mathrm{~mm}$ depth and the presence of an increased amount of ferrite in the near-surface microstructure. Hardness gradients had identical profiles in all specimens, including the initial annealed one. There were no substantial differences between hardness values. The average hardness (between $2 \mathrm{~mm}$ below the surface and the specimen mid-thickness) in quenched specimens was as follows: $637 \mathrm{HV} 1$ (water), $628 \mathrm{HV} 1$ (oil), 634 HV1 (salt). The material can thus be considered to harden uniformly, with no significant influence of the cooling medium used.

Nevertheless, hardness readings did illustrate some effects of cooling media and other parameters of the heat treatment (Fig. 5a). A more appreciable impact of the cooling medium can be seen in untempered specimens. However, these differences were not particularly large. Hardness values after quenching in salt baths at different temperatures are practically identical. Water-quenched specimens reached 648 HV10, the oil-quenched ones had a hardness of $636 \mathrm{HV} 10$ and those quenched in salt baths reached $624 \mathrm{HV} 10\left(150^{\circ} \mathrm{C}\right), 622 \mathrm{HV} 10\left(200^{\circ} \mathrm{C}\right)$ and 621 $\mathrm{HV} 10\left(250^{\circ} \mathrm{C}\right)$. In those specimens which were tempered after quenching, the differences between quenchants were even less distinct. The specimens, which had been quenched in water or oil and then tempered, exhibited almost 
identical hardness behaviours. Somewhat lower hardness (up to 35 HV10 less than in water-quenched specimens) was found in specimens quenched in salt baths, probably due to higher retained austenite content. After Q\&P process sequences, the hardness of specimens slowly decreased (by several HV points) with increasing quenching temperature (this can be seen in specimens 5-12 in Fig. 5). Greater changes in properties resulted from varying partitioning temperatures and times. The resulting hardness ranged from $620 \mathrm{HV} 10$ (zero holding time) to 540 HV10 (after the highest temperatures and longest partitioning times). The much higher hardness in the first Q\&P specimens resulted from the fact that their quenching temperatures were identical to the partitioning temperature in specimens 1-3 of QP05 series and by the zero holding time at the partitioning temperature in specimen QP06-4.
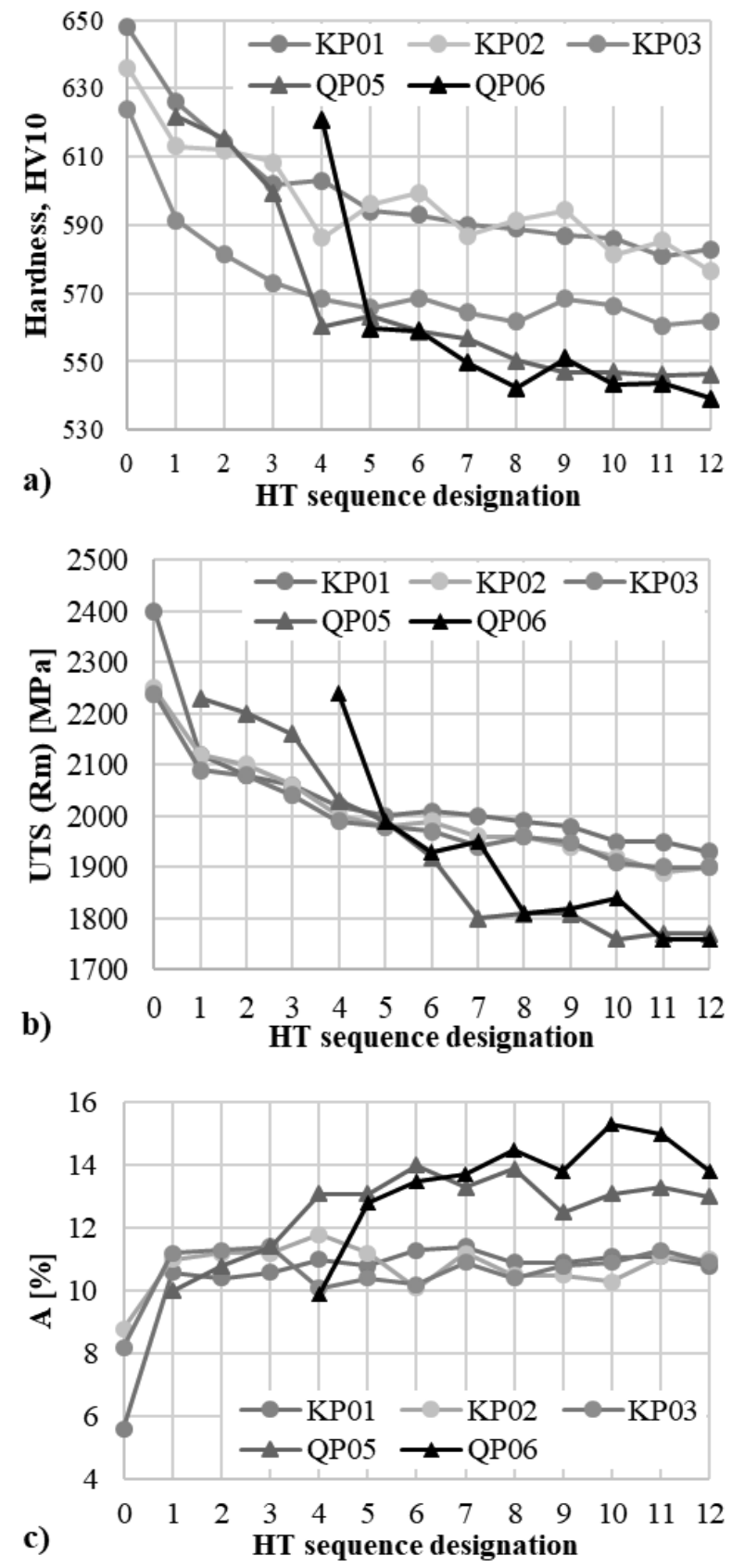

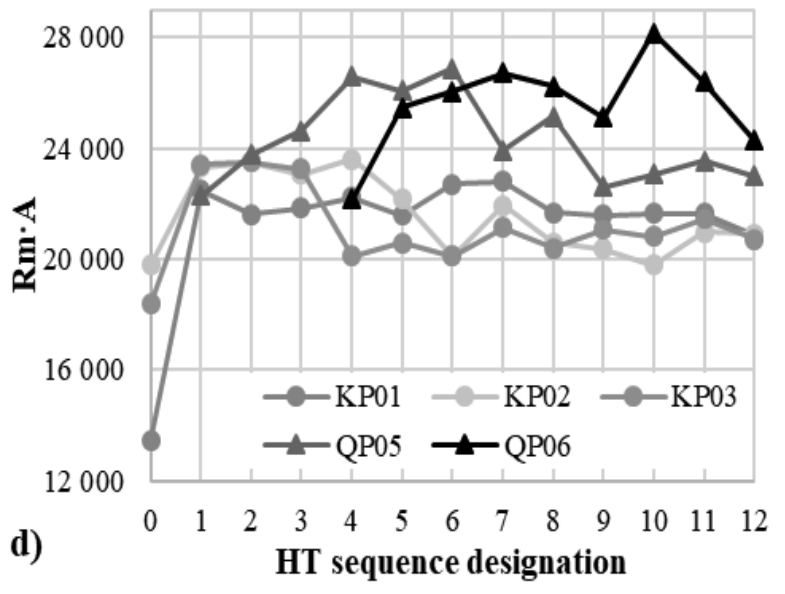

Fig. 5 Mechanical properties after various HT sequences. a) hardness HV10, b) tensile strength, c) elongation, d) product of tensile strength and elongation for

assessing and finding the best ratio of properties.

Results of the tensile tests showed that in conventional HT sequences that involved quenching and tempering, the type of quenchant had no substantial impact on final mechanical properties (Figure 5b, 5c). However, it did not apply to untempered specimens. Quenching in water led to the highest strength $(2400 \mathrm{MPa})$ and lowest elongation (5.6\%). After quenching in oil and salt bath, the strengths were slightly lower $(2250 \mathrm{MPa}$ and $2240 \mathrm{MPa}$, respectively) and elongations were higher $(8.8 \%$ and $8.2 \%$, respectively). The specimens quenched in the salt bath at various temperatures had virtually identical tensile strengths $(2240 \mathrm{MPa})$. Those quenched in baths at $200^{\circ} \mathrm{C}$ and $250^{\circ} \mathrm{C}$ had higher elongation (approx. $10 \%$ ). Subsequent tempering practically eliminated differences between the effects of various quenchants. Tensile strengths, 1900$2100 \mathrm{MPa}$, depended on the tempering sequence. The variation between specimens quenched in different quenchants was less than $50 \mathrm{MPa}$. In tempered specimens, elongation was almost independent on the quenchant, tempering time and tempering temperature. The range of elongation values was $10-12 \%$.

In Q\&P processing, elongation increased with increasing quenching temperature and partitioning temperature and time, whereas strength was decreasing slightly at the same time. The highest elongation and most favourable ratio of elongation and strength was associated with the quenching temperature of $250^{\circ} \mathrm{C}$. Graphs in Fig. $5 \mathrm{~b}$ and $5 \mathrm{c}$ show that strength and elongation after quenching at $250^{\circ} \mathrm{C}$ and tempering are equal to or higher than those after quenching at $200^{\circ} \mathrm{C}$. The best combinations of mechanical properties were obtained by partitioning at $300^{\circ} \mathrm{C}$ for 0 minutes (tensile strength of $1950 \mathrm{MPa}$ and elongation of $13.7 \%$ ) and at $350^{\circ} \mathrm{C}$ for 0 minutes (strength of $1840 \mathrm{MPa}$, elongation 15.3\%), (see Fig. 5d). It can be presumed that one factor contributing to the increased elongation is the higher austenite volume fraction found in specimens quenched in the salt bath (up to $8.4 \%$ in specimen KP03-05 quenched at $150^{\circ} \mathrm{C}$ and tempered at $250^{\circ} \mathrm{C}$ for 60 minutes). 


\section{Conclusion}

Experimental material, $42 \mathrm{SiCr}$ steel, was treated using conventional heat treatment and $\mathrm{Q} \& \mathrm{P}$ process sequences. The effects of cooling rates on microstructural evolution and mechanical properties were investigated. FE simulations using DEFORM ${ }^{\mathrm{TM}}$ software were performed. Results of these simulations, metallographic observation and data from hardness profile measurement confirmed that uniform hardening across the entire specimen crosssection was achieved in all cases. Quenched and tempered specimens exhibited nearly identical mechanical properties, regardless of the quenchant used. However, those quenched in the salt bath contained more austenite. Q\&Pprocessed material had appreciably higher elongation but somewhat lower strength, particularly those specimens which were quenched in the salt bath at higher temperatures. These results show that a salt bath at $250^{\circ} \mathrm{C}$ is the optimal means of quenching. Mechanical properties of Q\&P-processed material appeared to be affected by the higher proportion of retained austenite. The specimens quenched at $250^{\circ} \mathrm{C}$ with subsequent partitioning at $350^{\circ} \mathrm{C}$ showed elongations up to $15 \%$ and tensile strengths of about $1840 \mathrm{MPa}$. After partitioning at $300^{\circ} \mathrm{C}$, tensile strength reached up to $1950 \mathrm{MPa}$ and elongation was somewhat lower, approximately $14 \%$.

\section{Acknowledgement}

This contribution has been prepared under project LO1502 'Development of the Regional Technological Institute', under the auspices of the National Sustainability Programme I of the Ministry of Education of the Czech Republic aimed at supporting research, experimental development and innovation.

\section{References}

[1] XU, Yunbo; TAN, Xiaodong; YANG, Xiaolong; HU, Zhiping; PENG, Fei; WU, Di; WANG, Guodong. Microstructure evolution and mechanical properties of a hot-rolled directly quenched and partitioned steel containing proeutectoid ferrite. Materials Science \& Engineering: A. 2014, Vol. 607, pp. 460-475. https://DOI.org/10.1016/j.msea. 2014.04.030.
[2] JIRKOVÁ, Hana; MAŠEK, Bohuslav; WAGNER, Martin, F.-X.; LANGMAJEROVÁ, Danuše; KUČEROVÁ, Ludmila; KONETSCHNIK, Ruth; KIENER, Daniel. Influence of metastable retained austenite on macro and micromechanical properties of steel processed by the Q-P proces. Journal of Alloys and Compounds. 2014, Vol. 615, pp. S163-S168. DOI: 10.1016/j.jallcom. 2013.12.028.

[3] IBRAHIM, Khodr; BUBLÍKOVÁ, Dagmar; JIRKOVÁ, Hana; MAŠEK, Bohuslav. Stabilization of Retained Austenite in High-Strength Martensitic Steels with Reduced Ms Temperature. In: METAL 2015. Ostrava: TANGER, 2015, pp. 17. ISBN: 978-80-87294-58-1.

[4] BUBLÍKOVÁ, Dagmar, MAŠEK, Bohuslav, VOREL, Ivan, JENÍČEK, Štěpán. Stability of Retained Austenite in High-Strength Martensitic Steels with Low Ms Temperature. Manufacturing technology. 2017, Vol. 17, No. 4, pp. 428-433. ISSN: 1213-2489.

[5] KUČEROVÁ, Ludmila; JIRKOVÁ, Hana; KÁŇA, Josef. The suitability of 42SiCr steel for quenching and partitioning process. Manufacturing Technology. 2016, Vol. 16, No. 5, pp. $984-$ 989. ISSN: 1213-2489

[6] JIRKOVÁ, Hana; KUČEROVÁ, Ludmila; MAŠEK, Bohuslav. Effect of Quenching and Partitioning Temperatures in the Q-P Process on the Properties of AHSS with Various Amounts of Manganese and Silicon. Materials Science Forum. 2012, Vol. 706-709, pp. 2734-2739. ISSN: 02555476.

[7] RUBEŠOVÁ, Kateřina; VOREL, Ivan; JIRKOVÁ, Hana; JENÍČEK, Štěpán. Effects of Q\&P process parameters on properties of $42 \mathrm{SiCr}$ steel. Acta Metallurgica Slovaca. 2018, Vol. 24, No. 2, pp. 126-133. ISSN: 1335-1532.

[8] S\&I Technologies. Deform-2D/3D V11.2 [software]. May 2017. [Accessed on: 02/08/2108]. Available from: http://www.si-tech.at/en_deform/main.html. 